\title{
Seed Health of Groundnut (Arachis Hypogaea L.) as Affected by Seed Sources and Varieties
}

\author{
Wondimeneh Taye* \\ Wolaita Sodo University, Department of Plant Sciences, P.O. Box 138, Wolaita Sodo, Ethiopia \\ *Corresponding Authors: Wondimeneh Taye, Wolaita Sodo University, Department of Plant Sciences, \\ P.O. Box 138, Wolaita Sodo, Ethiopia

\begin{abstract}
Groundnut (Arachis hypogaea L.) is an important monoecious annual legume used as oilseed, food and animal feed all over the world. It plays a significant role in the livelihoods of marginal-farmers through income and nutritional security. The study assessed the health quality of groundnut (Arachis hypogaea L.) seed samples collected from formal and informal source from Babile woreda, eastern Harareghe, Ethiopia. The study was conducted using 100 sample households and seed samples from five peasant associations of Babile Wereda, Eastern Ethiopia. Twenty four seed samples of six groundnut varieties $1 \mathrm{k} . \mathrm{g}$ for each sample were collected both from the formal and informal sector to perform seed quality test in the laboratory for seed-health test using a complete randomized design (CRD). Seed-borne fungi, which included Fusarium oxysporum, Rhizoctonia bataticola, Aspergillus niger, Aspergillus flavus, Penicillium spp, Aspergillus glaucus, Aspergillus nidulans and Sclerotinia bataticola were associated with the groundnut seed. Among those Rhizoctonia bataticola, Aspergillus spp. and Fusarium oxysporum appeared dominantly. The seed health test of groundnut indicated that the presence of many type of seed-borne fungi from seed samples collected from formal and informal sources.
\end{abstract}

Keywords: Farmer seed, Groundnut, Seed health testing, Seed source

\section{INTRODUCTION}

Groundnut (Arachis hypogaea L.) is an important monoecious annual legume used as oilseed, food and animal feed all over the world (Upadhyaya et al., 2006). In addition to providing high quality edible oil easily digestible protein, nearly half of the 13 essential vitamins and 7 of the 20 essential minerals necessary for normal human growth, it produces high quality fodder for livestock. It thus plays a significant role in the livelihoods of marginal-farmers through income and nutritional security. In Ethiopia, groundnut production is adapted to warm climates and predominantly grown under rainfed conditions (Amare and Tamado, 2014). The total groundnut yield in the country was 1,296,364.18 tons for 2016/2017, with the productivity of 1.73 tons/ha (CSA, 2016/2017). Eastern and lowland part of the country, mainly East Hararghe zone, is the leading groundnut production area accounting for $43.4 \%$ of the total production. In this area, groundnut is replacing major crops like maize and sorghum (Amare and Tamado, 2014).

The crop is relatively new to Ethiopia as it was introduced from Eriterea to Hararghe in the early 1920's by the Italian explorers. Major groundnut producing areas include Babile, Beles, Didessa, Gambella and Pawe areas. Gamu Gofa, Illubabor, Gojam, Wello and Wellega are identified as potential production areas (Daniel, 2009). Seed supply system of groundnut in the developing countries indicates that all of the seed materials come from the general crop production rather than from crop grown especially for seed purpose. Use of seed that is produced on farm or obtained from relatives, friends or other informal channels is still by far the most important seed source for agriculture in developing countries including Ethiopia and is still important in more industrialized agricultural countries as well. Eighty percent of all seed in developing countries is estimated to be on farm produced seed. Of course, the percentage varies widely between crops (ICRISAT, 2015).

Seed of improved varieties is a costly input; more so in the case of groundnut, where the non-availability of improved variety seed is a major constraint in most of the groundnut growing countries. The private sector has little interest in the groundnut seed enterprise. There is the low seed multiplication ratio, bulky nature of the produce, quick loss of seed viability, high cost of transportation, low profit margin and the self-pollinated nature of the crop. Therefore the task of making the seed of improved groundnut 
varieties available to farmers in required quantities and at the right price lies with the public sector seed services. One of the most efficient means for the farmer to improve the productivity is to use high quality groundnut seeds (Ntare et al., 2008). However, due to different reasons production of quality groundnut seed production in Ethiopia is the major problem (Thijssen et al., 2008).

Babile is the leading groundnut producing area in Ethiopia. It serves as cash crop for farmers and generates profit for those who are involved in groundnut producing and other business dealing with groundnut. Groundnut research program at WARC and other collaborating centers have made efforts to overcome the constraints and to increase productivity of groundnut. However this improvement still does not overcome for the constraints of some fungal seed borne problems particularly for the two aflatoxins producing fungi: Aspergillus flavus and Aspergillus parasiticus (Ayalew et al., 1995; Eshetu, 2010; Chala et al., 2013; Mohammed and Chala, 2014; Mohammed et al., 2016) and low national average seed yield (below 1.12 tons per hectare) (CSA, 2017). Despite the fact that Babile is major groundnut producing area, there was lack of information on seed health of groundnut with respect to variety they used and the source of the seed. Thus, this research was conducted in order to assess the health quality of groundnut in the district.

\section{Material AND MethodS}

\subsection{Description of Samples Collection Area}

Groundnut seed samples were collected from eastern Hararghe zone Babile district which is the major groundnut producing area in the country and located in a semi-arid ecology $35 \mathrm{~km}$ from Harar and 570 $\mathrm{km}$ southeast of Addis Ababa. Its geographical position is within latitudes of $09^{0} 06^{\prime} 38^{\prime \prime}-09^{0} 14^{\prime} 24^{\prime \prime} \mathrm{N}$ and longitudes of $042^{0} 14^{\prime} 40^{\prime \prime}-042^{0} 19^{\prime} 18^{\prime \prime} \mathrm{E}$ and has an elevation range of 850-1950 m.a.s.l. (OBPED, 2000).

\subsection{Survey and Sampling}

\section{Seed system analysis}

A stratified sampling procedure followed by random sampling of farmers, as described by Bishaw et al. (2011), was employed. The study was undertaken by selecting five PA's of Babile woreda that produce groundnut. Total sizes of 100 respondents (farming households) were selected randomly from the selected five PAs.

The primary data necessary for the quantitative study was collected from sampled households by conducting formal survey using a structured interview schedule. Before the actual data collection several preparatory activities were carried out. First, to collect the data consistent to the questionnaire and in a proper manner, enumerators who are familiar to the culture and practice of the society were recruited for each sample PA and were given training. The training was focused on the purpose and contents of the questionnaire, techniques on how to approach and interview the respondents and collect the data using the questionnaire. Second, the interview schedule was pre-tested on ten randomly selected farm households from each PA before conducting the formal survey. Necessary improvements were made based on the feedback from the pre-test. The data were collected by five development agents of Agricultural development office with the assistance of district subject matter specialist who has better knowledge about and experience on the farming system of the study area and farmers' based groundnut seed production. The researcher was visiting each enumerator for cross checking and at the end of each day. All questionnaires were checked with the enumerators and clarifications were made.

To supplement primary data and to fill information gap; secondary data were collected from different sources namely records and reports of district office of Agriculture, regional Agricultural Research Institutes, Federal Ministry of Agriculture and Rural Development, Ethiopian Standard Authority and Ethiopian Seed Enterprises.

\subsection{Laboratory Analysis}

\section{Seed sampling}

The study was conducted both in laboratory and in the field. Seed samples which represented each variety were collected from each PA and samples of six varieties were collected from Babile research center. Six varieties of groundnut considered for quality analysis were Werer 961, Sedi, Roba, NC-4x, Sartu and Oldhale. Total sizes of 24 samples were collected and then as per ISTA procedure 1000g 
submitted sample of the varieties was taken for quality analysis. All tests were conducted according to ISTA rules and tolerance level were tested (ISTA, 1996).

\section{Seed health testing}

Seed health test was carried out using agar plate method. Ninety (90) undamaged seeds per sample were surface sterilized by quickly rinsing in $70 \%$ ethanol alcohol followed by socking in $1 \% \mathrm{NaOCl}$ for $1-2$ minutes and finally rinsed in distilled water two times. Seeds were placed on PDA (Potato Dextrose Agar) medium for each treatment, 30 seeds were placed in petridish with one replication represented by two petridishes and incubated for 1-2 weeks. During which growing fungi were identified and percentage of seed infection by total fungi and by individual species was recorded. In addition to this pure cultures were made to identify individual species. The fungi were identified based on their morphological features, such as colony characteristics, conidiophores, shape and septation of conidia and other structures observed under laboratory test.

\section{Methods of data analysis}

The analysis of variance (ANOVA) of the data on seed health was analyzed using the Statistical Analysis System computer software (SAS Version 9). Treatment means were separated using Duncan's Multiple Range tests (DMRT) and Least Significance Difference (LSD).

\section{RESULTS AND DISCUSSION}

\subsection{Seed Health of Groundnut Seed Samples Collected from Different Sources}

A number of diseases caused by fungi (early and late leaf spot, rust), bacteria and viruses, soil inhabiting insects (termite), aflatoxins produced by Aspergillus flavus and Aspergillus parasiticus were reported as major problems of groundnut production (Daniel, 2009). Shazia et al., (2004) recorded groundnut seed showed that seed was greatly infected by fungi Aspergillus flavus, Aspergillus niger, Fusarium oxysporum and Rhizoctonia solani. Of the various disease producing organisms, Fusarium solani, Fusarium oxysporum cause damping off of groundnut seedlings, Aspergillus flavus attack germinating groundnut seed and Aspergillus niger cause crown rot disease of groundnut.

In the present study, eight fungal species were found to be associated with groundnut seed samples. These seedborne fungi were Fusarium oxysporum, Rhizoctonia bataticola, Aspergillus niger, Aspergillus flavus, Penicillium spp. Aspergillus glaucus, Aspergillus nidulans and Sclerotinia bataticola (Table 1). Amare (1995) reported many more and most of these seed-borne fungi were isolated from groundnut seeds purchased from markets in Eastern Hararghe, Ethiopia. Infection by fungi was observed in different sources and varieties, i.e., from formal sector (Babile research center) and from farmers. The seed health quality of groundnut varieties obtained from different sources is presented in (Table 1). There was significant difference among individual seed samples infected and the level of infection.

Table1. Percentage occurrences of different fungi on groundnut samples collected from different seed sources in Babile, Eastern Ethiopia.

\begin{tabular}{|c|c|c|c|c|c|c|c|c|}
\hline \multirow[t]{2}{*}{ Varieties } & \multicolumn{8}{|c|}{$\%$ of fungus occurrence } \\
\hline & F.oxysporum & R.bataticola & A.niger & A.flavus & $\begin{array}{l}\text { Pencillium } \\
\text { spp. }\end{array}$ & A.glaucus & A.nidu & S.bataticola \\
\hline Oldhale FR & $(0.0)$ & $2.2(5)^{\mathrm{d}-\mathrm{g}}$ & $5.4(30)^{\mathrm{ba}}$ & $(0.0)$ & $3.2(11)^{\mathrm{ba}}$ & $(0.0)$ & $(0.0)$ & $0.7(1)^{\mathrm{dc}}$ \\
\hline Oldhale F1 & $2.1(4.4)^{\mathrm{dc}}$ & $3.3(11)^{\mathrm{a}-\mathrm{f}}$ & $0.7(1)^{\mathrm{e}}$ & $(0.0)$ & $0.7(1)^{\mathrm{bc}}$ & $2.5(6)^{b c}$ & $(0.0)$ & $2.8(8.8)^{\mathrm{bac}}$ \\
\hline Oldhale F2 & $1.8(3.3)^{\mathrm{dc}}$ & $2.8(8)^{\mathrm{b}-\mathrm{g}}$ & $4.2(19)^{\mathrm{bac}}$ & $2(4)^{\mathrm{a}-\mathrm{d}}$ & $2.5(6.6)^{\mathrm{bac}}$ & $3.1(10)^{\mathrm{ba}}$ & $(0.0)$ & $2.5(6.6)^{\mathrm{bdc}}$ \\
\hline Oldhale F3 & $(0.0)$ & $2.1(4.4)^{\text {egf }}$ & $2.7(7.8)^{\mathrm{edc}}$ & $(0.0)$ & $3.1(11)^{\mathrm{ba}}$ & $1.8(3.3)^{\mathrm{bc}}$ & $0.7(1.1)^{\mathrm{ba}}$ & $3.1(10)^{\mathrm{bac}}$ \\
\hline Oldhale F4 & $2.8(7.7)^{\mathrm{bc}}$ & $4.7(22)^{\mathrm{a}}$ & $3.7(13)^{\mathrm{bc}}$ & $0.7(1)^{\mathrm{dc}}$ & $1.4(2.2)^{\text {bac }}$ & $(0.0)$ & $(0.0)$ & $3.6(13)^{\mathrm{ba}}$ \\
\hline Oldhale F5 & $(0.0)$ & $0.7(1.1)^{\mathrm{g}}$ & $3.5(12)^{\mathrm{bdc}}$ & $(0.0)$ & $4(16)^{\mathrm{a}}$ & $(0.0)$ & $(0.0)$ & $3.5(12)^{\mathrm{ba}}$ \\
\hline Werer-961 FR & $(0.0)$ & $4.2(18)^{\mathrm{a}-\mathrm{d}}$ & $2(4)^{\text {edc }}$ & $(0.0)$ & $(0.0)$ & $(0.0)$ & $(0.0)$ & $(0.0)$ \\
\hline Werer-961 F1 & $2.3(5.5)^{\mathrm{dc}}$ & $1.8(3.3)^{\mathrm{g}}$ & $1.8(3.3)^{\mathrm{edc}}$ & $2(4)^{a-d}$ & $2.3(5)^{\mathrm{bac}}$ & $1.4(2.2)^{\mathrm{bc}}$ & $1.8(3.3)^{\mathrm{a}}$ & $2.8(7.7)^{\mathrm{bac}}$ \\
\hline Werer-961 F2 & $(0.0)$ & $1.8(3.3)^{\mathrm{gf}}$ & $3.1(11)^{b-e}$ & $3.1(10)^{\mathrm{a}}$ & $3.6(13)^{\mathrm{a}}$ & $(0.0)$ & $(0.0)$ & $1.4(2.2)^{\mathrm{dc}}$ \\
\hline Werer-961 F3 & $2.5(6.6)^{\mathrm{c}}$ & $3.1(10)^{\mathrm{a}-\mathrm{g}}$ & $1.8(3.3)^{\mathrm{edc}}$ & $2.8(7.7)^{\mathrm{ba}}$ & $1.8(3.3)^{\text {bac }}$ & $(0.0)$ & $(0.0)$ & $4.9(24)^{\mathrm{a}}$ \\
\hline Sedi FR & $(0.0)$ & $2.5(6)^{\mathrm{a}-\mathrm{g}}$ & $3.7(13)^{\mathrm{bdc}}$ & $2.1(4.4)^{\text {bac }}$ & $2.1(4.4)^{\text {bac }}$ & $2.1(4.4)^{\mathrm{bc}}$ & $(0.0)$ & $1.4(2.2)^{\mathrm{bdc}}$ \\
\hline Sedi F1 & $(0.0)$ & $4.4(19)^{\mathrm{a}-\mathrm{d}}$ & $1.8(3.3)^{\mathrm{edc}}$ & $2.3(5.5)^{\mathrm{a}-\mathrm{d}}$ & $0.7(1)^{\mathrm{bc}}$ & $(0.0)$ & $0.7(1.1)^{\mathrm{ba}}$ & $2.1(4.4)^{\mathrm{bdc}}$ \\
\hline Sedi F2 & $(0.0)$ & $2.5(6)^{\mathrm{a}-\mathrm{g}}$ & $6.3(39)^{\mathrm{a}}$ & $2.8(7.7)^{\mathrm{ba}}$ & $0.7(1)^{\mathrm{bc}}$ & $1.4(2.2)^{\mathrm{bc}}$ & $0.7(1.1)^{\mathrm{ba}}$ & $1.4(2.2)^{\mathrm{bdc}}$ \\
\hline Sedi F3 & $(0.0)$ & $2.6(7)^{\mathrm{a}-\mathrm{g}}$ & $2.3(5.6)^{\mathrm{edc}}$ & $(0.0)$ & $(0.0)$ & $0.7(1)^{\mathrm{c}}$ & $(0.0)$ & $(0.0)$ \\
\hline Sedi F4 & $(0.0)$ & $4.2(18)^{\mathrm{a}-\mathrm{d}}$ & $3(9)^{b-e}$ & $2.1(4.4)^{\mathrm{a}-\mathrm{d}}$ & $0.7(1)^{\mathrm{bc}}$ & $(0.0)$ & $(0.0)$ & $1.8(3.3)^{\mathrm{bdc}}$ \\
\hline Sedi F5 & $1.4(2.2)^{\mathrm{dc}}$ & $1.8(3.3)^{\mathrm{g}}$ & $3.7(13)^{\mathrm{bdc}}$ & $2.8(7)^{\mathrm{bac}}$ & $(0.0)$ & $(0.0)$ & $1.4(2.2)^{\mathrm{ba}}$ & $1.4(2.2)^{\mathrm{bdc}}$ \\
\hline NC-4X FR & $3.9(15.5)^{\mathrm{d}}$ & $3.1(10)^{\mathrm{a}-\mathrm{g}}$ & $1.8(3.3)^{\mathrm{edc}}$ & $(0.0)$ & $2.8(7.7)^{\text {bac }}$ & $(0.0)$ & $(0.0)$ & $3.1(10)^{\mathrm{bac}}$ \\
\hline
\end{tabular}


Seed Health of Groundnut (Arachis Hypogaea L.) as Affected by Seed Sources and Varieties

\begin{tabular}{|l|l|l|l|l|l|l|l|l|}
\hline NC-4X F1 & $4.3(18.8)^{\mathrm{a}}$ & $3.9(15)^{\mathrm{a}-\mathrm{e}}$ & $3.5(12)^{\mathrm{b}-\mathrm{e}}$ & $2(4)^{\mathrm{a}-\mathrm{d}}$ & $0.7(1)^{\mathrm{bc}}$ & $(0.0)$ & $(0.0)$ & $1.8(3.3)^{\mathrm{bdc}}$ \\
\hline Sartu F1 & $2.3(5.55)^{\mathrm{bc}}$ & $2.6(6.6)^{\mathrm{c}-\mathrm{g}}$ & $1.4(2)^{\mathrm{bd}}$ & $1.4(2.2)^{\mathrm{bdc}}$ & $2.8(7.7)^{\mathrm{bac}}$ & $4.2(17)^{\mathrm{a}}$ & $(0.0)$ & $1.4(2.2)^{\mathrm{dc}}$ \\
\hline Sartu FR & $(0.0)$ & $2.6(6.6)^{\mathrm{c}-\mathrm{g}}$ & $3.1(10)^{\mathrm{edc}}$ & $(0.0)$ & $(0.0)$ & $(0.0)$ & $1.8(3.3)^{\mathrm{a}}$ & $2.1(4.4)^{\mathrm{bdc}}$ \\
\hline Sartu F2 & $2.1(4.4)^{\mathrm{dc}}$ & $1.4(2)^{\mathrm{gf}}$ & $3(9)^{\mathrm{b}-\mathrm{e}}$ & $(0.0)$ & $2.6(6.6)^{\mathrm{bac}}$ & $1.4(2.2)^{\mathrm{bc}}$ & $(0.0)$ & $2.1(4.4)^{\mathrm{bdc}}$ \\
\hline Roba FR & $(0.0))$ & $4.6(21)^{\mathrm{ba}}$ & $1.9(3.3)^{\mathrm{edc}}$ & $1.4(2.2)^{\mathrm{bdc}}$ & $(0.0)$ & $(0.0)$ & $0.7(1.1)^{\mathrm{ba}}$ & $2.4(5.5)^{\mathrm{bdc}}$ \\
\hline Roba F1 & $(0.0)$ & $4.5(20)^{\mathrm{bac}}$ & $2(4)^{\mathrm{edc}}$ & $(0.0)$ & $2(4)^{\mathrm{bac}}$ & $(0.0)$ & $(0.0)$ & $3.2(11)^{\mathrm{bac}}$ \\
\hline Roba F2 & $(0.0)$ & $3.6(13)^{\mathrm{ac}}$ & $2(4)^{\mathrm{edc}}$ & $0.7(1)^{\mathrm{dc}}$ & $2.8(7.7)^{\mathrm{ba}}$ & $1.4(2.2)^{\mathrm{bc}}$ & $(0.0)$ & $2.4(5.5)^{\mathrm{bdc}}$ \\
\hline Mean & $1.1(3.08)$ & $3(10.1)$ & $3(9.8)$ & $1.2(2.8)$ & $1.9(4.7)$ & $0.9(2.2)$ & $0.4(0.6)$ & $2.2(6.2)$ \\
\hline
\end{tabular}

Values with the same letter in a column are not significantly different at $\leq 5 \%$ level of the DMRT test. $\mathrm{FR}=$ formal; F1= farmer1; F2=farmer2; F3=farmer3; F4=farmer4; F5=farmer5. F.oxysporum = Fusarium oxysporum; R.bataticola=Rhizoctonia bataticola; A.niger=Aspergillus niger; A.flavus=Aspergillus flavus; A.glaucus=Aspergillus glaucus; A.nidu=Aspergillus nidulans; S.bataticola $=$ Sclerotinia bataticola . Percentage values were square root transformed and values in parenthesis are the original value in percentage.

In many reports, the major disease of groundnut was due to Aspergillus spp. Aspergillus was the most common genus and six species of Aspergillus spp of which A.niger, A. flavus and Aspergillus spp were the most prevalent. Fusarium was the second most common genus and Fusarium oxysporum was the most predominant species in groundnut seed (Amare, 1995). Similarly in this study this fungus was also observed dominantly. Regarding with the Percentage occurrences of fungi the highest infection was observed for Rhizoctonia bataticola among other species with $10.1 \%$ of infection. Aspergillus spp were also the most frequent fungi having mean infection of $15.4 \%$ (Aspergillus niger, Aspergillus flavus, Aspergillus glaucus and Aspergillus nidulans with 9.8\%, 2.8\%, 2.2\% and 0.6\%) infection respectively. Other fungi associated with groundnut seed were Sclerotinia bataticola, Pencillium spp. and Fusarium oxysporum with mean infection of $6.23 \% .4 .7 \%$ and $3.08 \%$ respectively. In case of Aspergillus nidulans the mean infection level $(0.6 \%)$ was the least as compared to other pathogens.

The seed health test of groundnut seed showed significant difference of infection by seedborne diseases across different sources (formal and informal). Fusarium oxysporum appeared to be a

major groundnut production problem in the informal (Ifa and Shek Abdi) seed source. The result also indicated higher infection with Rhizoctonia bataticola, (20\%) Aspergillus niger (15.44\%), Aspergillus flavus (4.07\%), Pencillium spp. (8.33\%), Aspergillus glaucus(4.59\%) and Sclerotinia bataticola (11.8\%) from informal seed samples (Table 2).

There was also significant difference on health quality among groundnut varieties collected from different sources. The highest level of infection with Fusarium oxysporum was observed from NC-4X variety with a mean infection of $9.44 \%$. A total of six spp were isolated from NC-4X variety which indicated in terms of fungus spp appeared to be relatively low. Moreover, 6.94\%, 3.33\%, $2.59 \%$ and $0.37 \%$ fusarium infection was reported on Werer-961, Sartu, Oldhale and Sedi groundnut varieties respectively. Seed samples from Roba variety did not show any fusarium infection. But maximum values for infection by Rhizoctonia bataticola $(18.4 \%)$ were recorded in this variety. The highest infection with Aspergillus niger (14.88\%), Pencillium spp. (8.14\%) and Sclerotinia bataticola (8.7\%) was observed from seed samples of farmers cultivar Oldhale variety (Table 2).

Table2. Seed health test of groundnut by seed source and varieties in Babile, Eastern Ethiopia.

\begin{tabular}{|c|c|c|c|c|c|c|c|c|}
\hline \multirow{2}{*}{ Seed source } & \multicolumn{8}{|c|}{$\%$ of fungus occurrence } \\
\hline & F.oxysporum & R.bataticola & A.niger & A.flavus & $\begin{array}{l}\text { Pencillium } \\
\text { spp. }\end{array}$ & A.glaucus & A.nidu & S.bataticola \\
\hline Formal & $2.99^{\mathrm{b}}$ & $11.29^{\mathrm{b}}$ & $10.74^{\text {ba }}$ & $1.11^{\mathrm{a}}$ & $3.88^{\mathrm{a}}$ & $0.74^{\mathrm{c}}$ & $0.74^{\mathrm{a}}$ & $3.88^{\mathrm{b}}$ \\
\hline Ifa & $6.74^{\mathrm{a}}$ & $12.59^{\mathrm{b}}$ & $4.44^{\mathrm{c}}$ & $2.77^{\mathrm{a}}$ & $3.51^{\mathrm{a}}$ & $4.59^{\mathrm{a}}$ & $0.74^{\mathrm{a}}$ & $5.29^{\mathrm{b}}$ \\
\hline Tula & $1.55^{\mathrm{b}}$ & $6.66^{\mathrm{cb}}$ & $15.44^{\mathrm{a}}$ & $4.06^{\mathrm{a}}$ & $7.11^{\mathrm{a}}$ & $3.33^{\text {ba }}$ & $0.22^{\mathrm{a}}$ & $4.22^{\mathrm{b}}$ \\
\hline Kito & $2.22^{\mathrm{b}}$ & $7.4^{\mathrm{cb}}$ & $5.55^{\mathrm{bc}}$ & $2.59^{\mathrm{a}}$ & $4.81^{\mathrm{a}}$ & $1.48^{\mathrm{bc}}$ & $0.37^{\mathrm{a}}$ & $11.48^{\mathrm{a}}$ \\
\hline Shek Abdi & $3.88^{\text {ba }}$ & $20^{\mathrm{a}}$ & $10.11^{\text {ba }}$ & $2.77^{\mathrm{a}}$ & $1.66^{\mathrm{a}}$ & 0.00 & 0.00 & $8.33^{\text {ba }}$ \\
\hline Shek Hussien & $1.11^{\mathrm{b}}$ & $2.22^{\mathrm{c}}$ & $12.77 \mathrm{a}$ & $3.78^{\mathrm{a}}$ & $8.33^{\mathrm{a}}$ & 0.00 & $1.11^{\mathrm{a}}$ & $7.22^{\mathrm{ba}}$ \\
\hline Mean & 3.08 & 10.1 & 9.8 & 2.8 & 4.7 & 2.2 & 0.6 & 6.23 \\
\hline LSD & 3.7 & 6.01 & 5.97 & 4.56 & 6.22 & 2.87 & 0.43 & 4.89 \\
\hline \multicolumn{9}{|l|}{ Varieties } \\
\hline Oldhale & $2.59^{\mathrm{b}}$ & $8.88^{\mathrm{cb}}$ & $14.88^{\mathrm{a}}$ & $0.92^{\mathrm{b}}$ & $8.14^{\mathrm{a}}$ & $3.33^{\mathrm{b}}$ & $0.18^{\text {ba }}$ & $8.7^{\mathrm{a}}$ \\
\hline Werer-961 & $6.94^{\mathrm{a}}$ & $8.61^{\mathrm{cb}}$ & $6.55^{\mathrm{b}}$ & $5.55^{\mathrm{a}}$ & $5.55^{\mathrm{a}}$ & $0.55^{\mathrm{c}}$ & $0.83^{\text {ba }}$ & $8.61^{\mathrm{a}}$ \\
\hline Sedi & $0.37^{\mathrm{b}}$ & $10^{\mathrm{cb}}$ & $13.88^{\mathrm{a}}$ & $5.00^{\mathrm{a}}$ & $1.29^{\mathrm{a}}$ & $1.29^{\mathrm{cb}}$ & $0.74^{\text {ba }}$ & $2.4^{\mathrm{c}}$ \\
\hline NC-4X & $9.44^{\mathrm{a}}$ & $12.77^{b}$ & $8.77^{\text {ba }}$ & $2.22^{\mathrm{b}}$ & $4.44^{\mathrm{a}}$ & 0.00 & 0.00 & $6.66^{\text {bac }}$ \\
\hline Sartu & $3.33^{\mathrm{b}}$ & $5.18^{\mathrm{c}}$ & $8.03^{\mathrm{b}}$ & $0.74^{\mathrm{b}}$ & $3.81^{\mathrm{a}}$ & $6.66^{\mathrm{a}}$ & $1.11^{\mathrm{a}}$ & $3.7^{\mathrm{bc}}$ \\
\hline Roba & 0.00 & $18.14^{\mathrm{a}}$ & $5.07^{\mathrm{b}}$ & $1.11^{\mathrm{b}}$ & $3.97^{\mathrm{a}}$ & $0.74^{\mathrm{cb}}$ & $0.37^{\text {ba }}$ & $7.4^{\mathrm{ba}}$ \\
\hline
\end{tabular}


Seed Health of Groundnut (Arachis Hypogaea L.) as Affected by Seed Sources and Varieties

\begin{tabular}{|l|l|l|l|l|l|l|l|l|}
\hline Mean & 3.08 & 10.19 & 9.8 & 2.58 & 4.7 & 2.2 & 0.6 & 6.23 \\
\hline LSD & 3.57 & 4.86 & 6.66 & 2.28 & 6.87 & 2.68 & 0.99 \\
\hline
\end{tabular}

Values with the same letter in a column are not significantly different at $\leq 5 \% \mathrm{P}$ level. F.oxysporum $=$ Fusarium oxysporum; R.bataticola=Rhizoctonia bataticola; A.niger=Aspergillus niger;

A.flavus=Aspergillus flavus; A.glaucus=Aspergillus glaucus; A.nidu=Aspergillus nidulans; S.bataticola $=$ Sclerotinia bataticola .

\section{CONCLuSion}

This study was initiated to assess the seed health of groundnut with respect to its source and variety. The primary data necessary for the study were collected through formal interviews of 100 sample farmers who grew groundnut on their farm drawn from five PAs of Babile woreda. Seed samples of six varieties of groundnut were collected from five PAs and Babile research center for laboratory analysis. A $1 \mathrm{~kg}$ of seed of 24 samples of six varieties was collected from five PAs and Babile research center for seed quality analysis. Each seed sample was tested for their seed health. The varieties tested were Sedi, Roba, Were-961, NC-4x, Oldhale and Sartu.

The informal groundnut seed system was dominant in Babile woreda and the initial source of groundnut varieties was for the farmers own saved seed, gift from parents, purchased and loan from farmers were the major seed sources. Seed samples collected from different sources were analyzed and compared in terms of seed health quality. There was significant difference among individual seed samples as well as among different seed sources and varieties. Fungal pathogens have been identified from the seed samples with varying proportion of infected seed samples and percentage infection. These seed-borne fungi were Fusarium oxysporum, Rhizoctonia bataticola, Aspergillus niger, Aspergillus flavus, Penicillium spp., Aspergillus glaucus, Aspergillus nidulans and Sclerotinia bataticola. Among those Rhizoctonia bataticola, Aspergillus spp and Fusarium oxysporum appeared dominantly. Contamination with rhizopus and fungal disease remain a major problem. The seed health test of groundnut indicated that the presence of many type of seed-borne fungi from seed samples collected from formal and informal sources. It showed significant differences among individual seed samples as well as between different seed sources and varieties.

\section{REFERENCES}

[1] Amare A. 1995. Studies on Mycoflora and aflatoxins of groundnut seeds in Eastern Ethiopia. M.Sc. Thesis, Alemaya University of Agriculture, Ethiopia. 65p.

[2] Amare K, Tamado T . 2014. Genotype by environment interaction and stability of pod yield of elite breeding lines of groundnut (Arachis hypogaea L.) in eastern Ethiopia. Science, Technology and Arts Research Journal $3(2): 43-46$.

[3] Ayalew A, Dawit A, Mengistu H .1995. Mycoflora, aflatoxins and resistance of groundnut cultivars from eastern Ethiopia. SINET Ethiopian Journal of Science 18(1):117-131.

[4] Bishaw, Z., Struik, P.C., Van Gastel, A.J.G., 2011. Wheat and barley seed systems in Syria: Farmers' varietal perception, seed sources and seed management. Inter. J. Plant Prod. 5 (4), 323-347.

[5] Central Statistical Agency (CSA) . 2016/2017. Agricultural Sample Survey for 2016/2017 Crop Season. Volume I. Report on Area and Production of Crops for Private Peasant Holdings (Meher Season). April, 2017, Addis Ababa, Ethiopia. Available at: http://www.csa.gov.et/ehioinfointernal?download=816:livestockreport-2009-ec-2016-17

[6] Chala A, Mohammed A, Ayalew A, Skinnes H . 2013. Natural occurrence of aflatoxins in groundnut (Arachis hypogaea L.) from eastern Ethiopia. Food Control 30(2):602-605.

[7] CSA (Central Statistical Authority), 2017. Area and production of crops Volume I statistical Bulletins. Central Statistical Authority, Addis Ababa, Ethiopia. 446p.

[8] Eshetu L . 2010. Aflatoxin content of peanut (Arachis hypogaea L.) in relation to shelling and storage practice of Ethiopian farmers. MSc Thesis. Addis Ababa University P 81.

[9] FAOSTAT (Food and Agricultural Organization), 2010. Statistical data bases Available at http://faostat. fao.org/. Accessed on January, 28, 2011.

[10] ICRISAT (International Crops Research Institute for the Semi-Arid Tropics) 2015. Groundnut seed system, An Analysis of farmers' perception and alternative strategies, in Andhra Pradeh; 11p.

[11]ISTA (International Seed Testing Association), 2005. International rules for seed testing edition 2005. International Seed Testing Association (ISTA), Bassersdorf CH-Switzerland.

[12] Mohammed A, Chala A .2014. Incidence of Aspergillus contamination of groundnut (Arachis hypogaea L.) in eastern Ethiopia. African Journal of Microbiology Research 8(8):759-765.

International Journal of Research Studies in Agricultural Sciences (IJRSAS) 
[13] Mohammed A, Chala A, Mashilla D, Fininsa C, Hoisington A, Sobolev S, Arias S . 2016. Aspergillus and aflatoxin contamination of groundnut (Arachis hypogaea L.) and groundnut cake in Eastern Ethiopia. Food Additives and Contaminants - Part B.

[14] Ntare N.J,, Waliyar F and Ramouch,M. (eds.), 2008. Groundnut seed system in west Africa. CFC technical paper No 40. Amsterdam, the Netherlands; common fund for commodities; International Crop Research Institute for Semi-Arid Tropics. 232p.

[15] OBPED (Oromia Bureaus of Planning and Economic Development), 2016. Physical and socio- economic profiles of 180 districts of Oromia. Physical Planning Department, Addis Abeba.

[16] Shazia, R. Shahnaz, D. and Abdul, G. 2004. Location of fungi in groundnut seed Department of Botany, University of Karachi, Karachi-75270, Pakistan. Pakistan Journal of Botany, 36(3):663-668.

[17] Upadhyaya HD, Reddy LJ, Gowda CL, Singh S .2006. Identification of diverse groundnut germplasim: Sources of early maturity in a core collection. Field Crops Research 97(2-3):261-271.

Citation: Wondimeneh Taye, "Seed Health of Groundnut (Arachis Hypogaea L.) as Affected by Seed Sources and Varieties" International Journal of Research Studies in Agricultural Sciences (IJRSAS), 2020; 6(5), pp. 21 26, http://dx.doi.org/ 10.20431/2454-6224.0605003

Copyright: (c) 2020 Authors. This is an open-access article distributed under the terms of the Creative Commons Attribution License, which permits unrestricted use, distribution, and reproduction in any medium, provided the original author and source are credited. 